\section{ACCUMULATION AND CELLULAR EFFECTS OF HEAVY METALS IN BENTHIC AND PLANKTONIC ALGAE}

\author{
Linda Sicko-Goad and Diane Lazinsky
}

Great Lakes Research Division, University of Michigan, Ann Arbor, MI 48109

Concentration levels of heavy metals which are found in the Laurentian Great Lakes (ppb range) can be accumulated by algae and can exert toxicological effects on algal species in natural assemblages. One of the most common mechanism for sequestering metals in algae is the incorporation of these metals into polyphosphate bodies. Presumably, the movement of species that have sequestered metals in this manner by water mass movements and circulation patterns could lead to the dispersal of metals to areas that are removed from the point source of pollution. Evidence was also obtained that indicated that tubificid worms in sediments from Saginaw Bay had lead accumulations in the cells lining the gut. The gut contents, as examined by $x$-ray energy dispersive analysis, included blue-green algae that had polyphosphate bodies and lead associated with them, leading us to believe that there is a transfer of lead from the algate in the gut into the tubificid body.

Surveys of whole cell mounts of a variety of algae including many benthic forms from Saginaw Bay and the Saginaw River showed no appreciable accumulation of heavy metals in algae, with the exceptions that many cells had quantities of iron and that certain river samples of Pediastmum contained high concentrations of aluminum.

Lake Michigan natural algal assemblages from nearshore and offshore areas incubated in lake water with 5, 10, or $20 \mathrm{ppb}$ of lead, copper and cadmi um revealed that lead was concentrated in both nearshore and offshore algae. No copper or cadmium was apparently accumulated in the species examined. Great Lakes isolates as well as several cultured species were treated in a similar fashion by incubation in medium containing $0.1 \mu \mathrm{g}$-at $/ 1$ of $\mathrm{Cu}, \mathrm{Pb}, \mathrm{Cd}$, or $\mathrm{Zn}$. Scenedesmus Sp. accumulated no metals. The blue-greens accumulated metals to different degrees, but with no evidence of copper accumulation.

Quantitative cytological examination of several algal species incubated in copper and lead demonstrated that in general, algae experience more cytological changes as a response to copper than when compared with lead exposure. Copper appears to affect the phosphate uptake mechanism. Exposure to lead or copper also results in the formation of membranous organelles resembling residual bodies. Electron cytochemistry of a cultured diatom, Diatoma tenue var. ezongation demonstrates a positive reaction for acid phosphatase ( $\mathrm{pH} \mathrm{5.0)}$ in the areas of residual body-like organelles. Exposure of three algae in a natural assemblage to the metals $\mathrm{Pb}$ and $\mathrm{Cu}$ resulted in more statistically significant cytological differences in an alga that can, of the three, be classified as a cleaner water species.

These results suggest that in addition to metal exclusion, two other mechanisms are responsible for successful adaptation to heavy metals in Great Lakes algae. (1) Heavy metals, especially $\mathrm{Pb}, \mathrm{Cd}$, and $\mathrm{Zn}$ can be incorporated in polyphosphate bodies. Metals incorporated in this manner can be transferred by direct consumption through the food chain as we have demonstrated in the tubificid worm. Mobilization of polyphosphate in phosphorus poor waters could internally mobilize the metal in the same organism, eventually leading to death of the organism or release of the metal to the soluble phase in an area distant from the source of the metal. (2) Heavy metals, though not present in detectable levels in the cells may be immobilized within the cell in vacuoles. In certain organisms, these might be excreted back into the environment or produce cellular changes which may prevent certain organisms from growing and competing successfully in areas where the metals persist, leading to the growth of undesirable species. Supported by U.S. Environmental Protection Agency Grant R805146. 

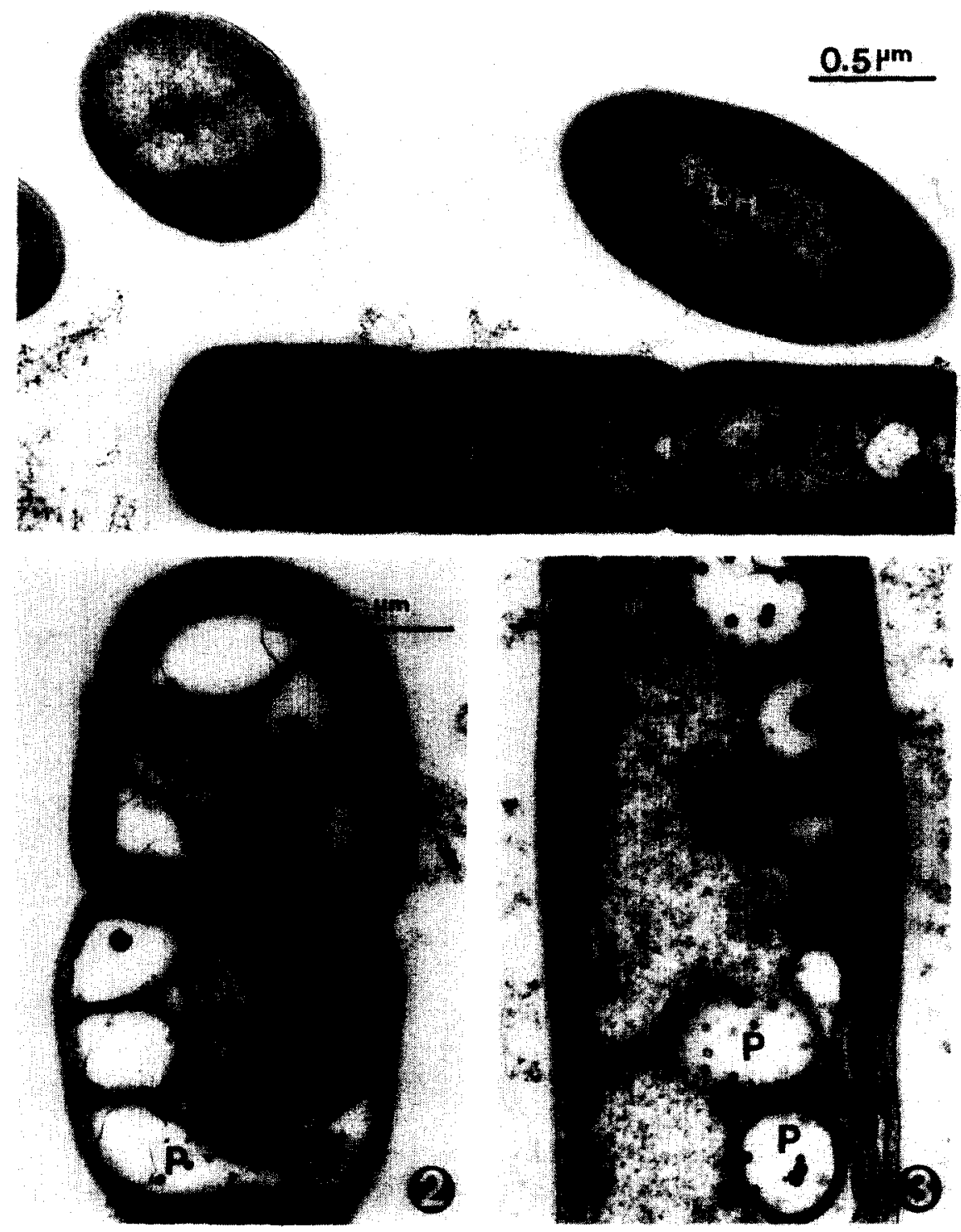

FIGS. 1-3. Plectonema boryanum Gom. Series of pictures from an experiment where the bluegreen was subjected to heavy metal exposure $(0.1 \mathrm{Hg}-\mathrm{at} / \mathrm{L})$ for 3 days. In general, metal exposure, especially $\mathrm{Zn}$ and $\mathrm{Pb}$, resulted in increased numbers and volume of polyphosphate. In addition, the relative volume $\left(V_{v}\right)$ of intrathylakoidal space also increased with both $Z$ in and $\mathrm{Cd}$ treatments.

FIG. 1. Control (4 day) cell of $P$. boryanum grown in modified Fitzgerald's medium with no metal exposure. Note the regular cell septae (arrows) and polyhedral bodies (PH).

FIG. 2. Cadmium treated ce11. Note increased vacuolization and the presence of numerous polyphosphate bodies $(P)$.

FIG. 3. Zinc treated cell. Vacuolization and polyphosphate numbers and volume are greatest with this metal exposure. Division abnormalities (unequal or incomplete divisions) were also frequently observed with $\mathrm{Zn}$ treatment. 